\title{
Diverse sensitivity of melanoma cells originated from various parts of the tumor to dacarbazine treatment
}

\author{
Anna Komina, Anton Averchuk, Nadezhda Palkina, Mariia Aksenenko, and Tatiana Ruksha \\ Department of Pathophysiology, Krasnoyarsk State Medical University, Krasnoyarsk, Russian \\ Federation
}

\begin{abstract}
Melanoma is an aggressive disease with the highest death rate within cutaneous malignancies. One of the reasons for it is the tumor heterogeneity and the formation of subclones with different sensitivity to anti-cancer therapy.

This study was aimed to evaluate the response of melanoma cells from different tumor sites to dacarbazine treatment. Two fragments of primary melanoma from 35-yearsold female patient were isolated and cultured: from the central and peripheral part of the tumor. The cells were treated with different concentrations of dacarbazine $-250 \mathrm{mg} / \mathrm{l}, 500 \mathrm{mg} / \mathrm{l}$, $750 \mathrm{mg} / \mathrm{l}$ amd $1000 \mathrm{mg} / \mathrm{l}$ - and then cell viability/proliferation was estimated using MTT-test after 24 hours of incubation. It was shown that cells from central and marginal sites had similar sensitivity to the treatment and demonstrate $50 \%$ loss of viability at the concentration of dacarbazine $885.0 \mu \mathrm{g} / \mathrm{mL}$ and 792.5 $\mu \mathrm{g} / \mathrm{mL}$ respectively (according to linear approximation) (Fig. 1.A).
\end{abstract}

Further we evaluated the effect of $1000 \mu \mathrm{g} / \mathrm{mL}$ of dacarbazine on cell apoptosis, migration and invasion after 24 hours. Dacarbazine treatment induced $30 \%$ decrease of alive melanoma cells originated from the central part of the tumor but among melanoma cells from marginal zone $5.4 \%$ only were alive (Fig. 1.B). 62.2\% cells from the center of tumor were observed at the early apoptosis stage while $54.5 \%$ cells from marginal zone were at later apoptosis/necrosis.

Migration and invasive capacities were increased in melanoma cells originated from central part of the tumor after 24 hours incubation with $1000 \mu \mathrm{g} / \mathrm{mL}$ of dacarbazine while melanoma cells from peripheral part diminished their ability to migration and invasion after dacarbazine incubation (Fig. 1.C,D). Our study demonstrates different sensitivity to dacarbazine of melanoma cells depending on tumor site that could be due to heterogenic pattern of tumor cells and need to be considered for melanoma treatment administration.

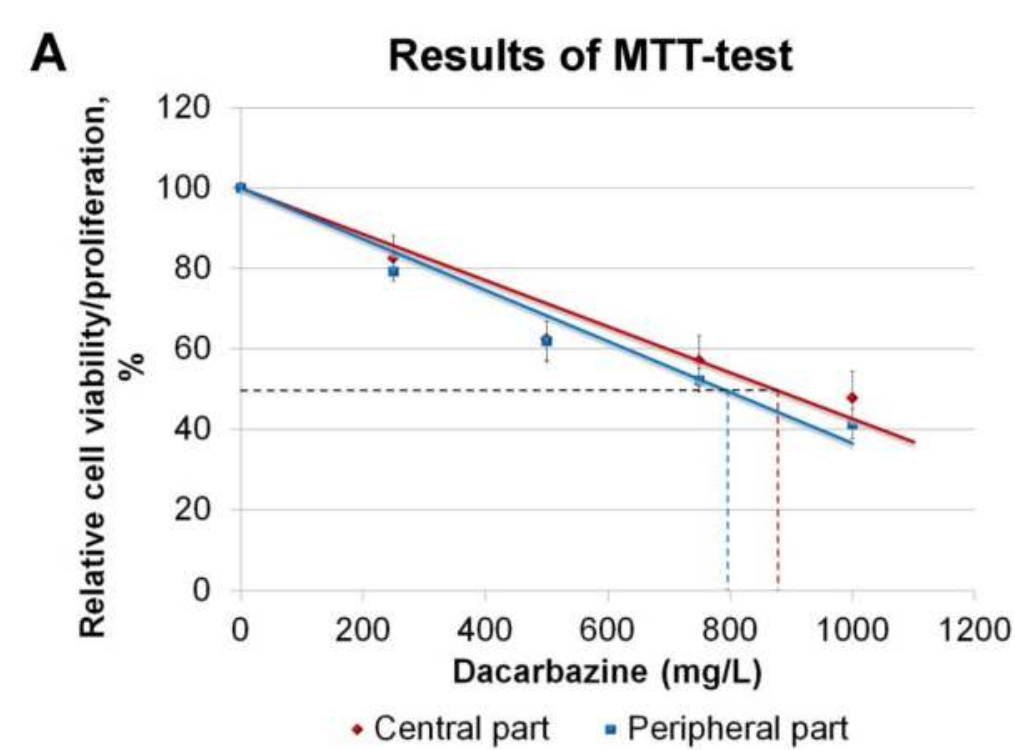

B

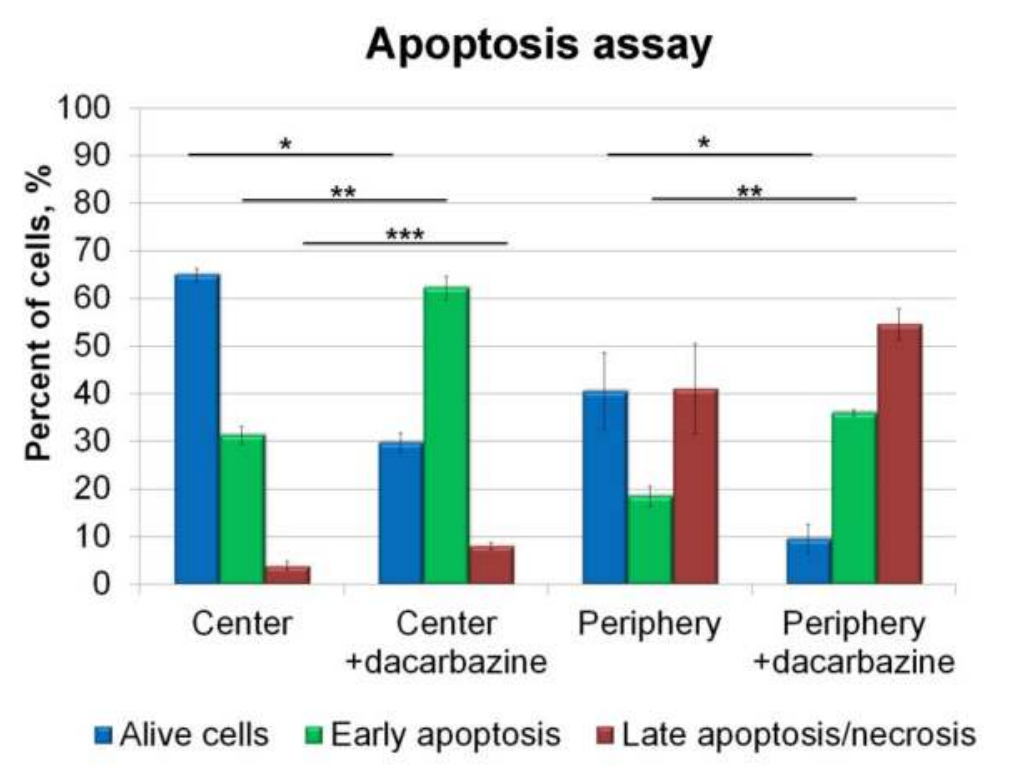

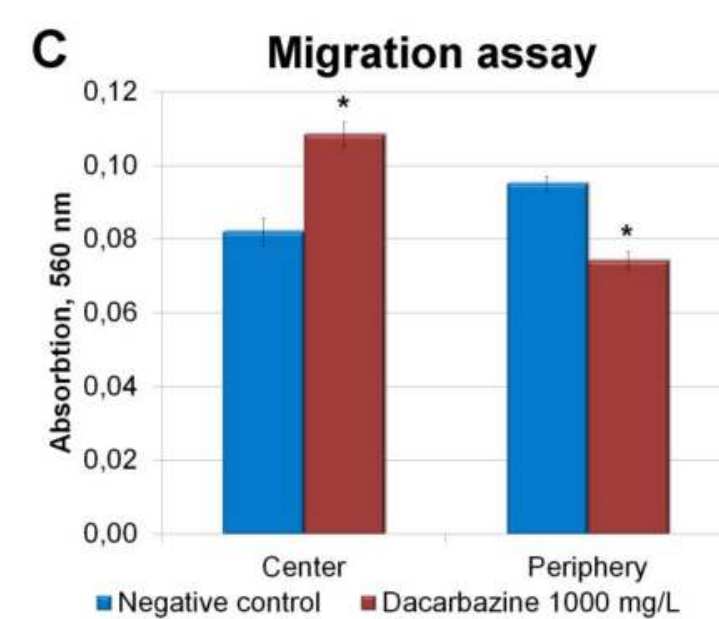

D

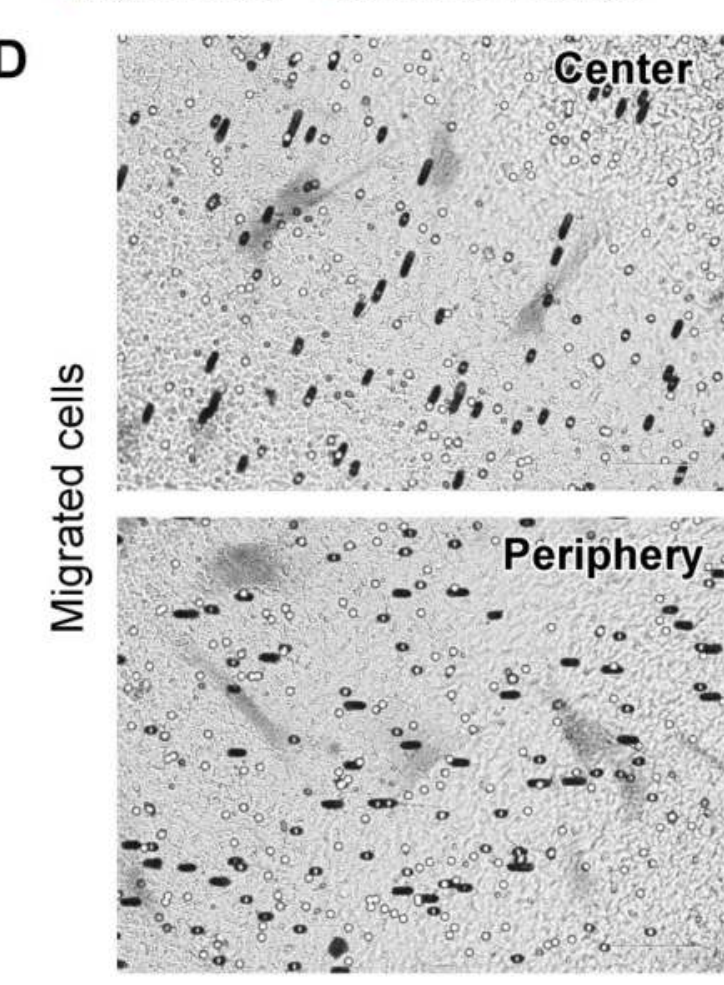

Invasion assay
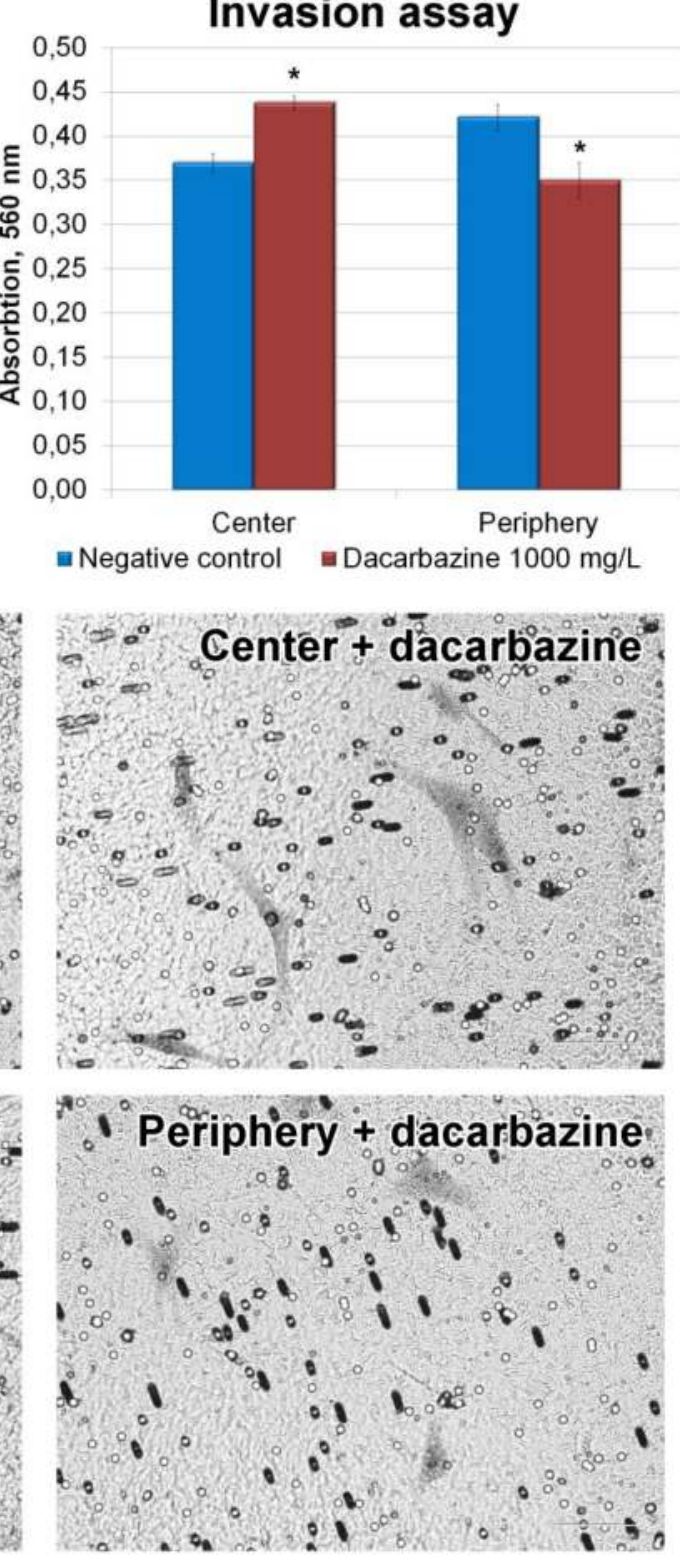

Fig. 1. The influence of dacarbazine treatment on melanoma cells originated from central and peripheral part of the tumor. Data presented as mean \pm standard error of mean.

(A) Change in viability/proliferation of melanoma cells from depending on the concentration of dacarbazine (MTT-test). Dotted lines indicate 50\% inhibitory concentration of dacarbazine (IC50). (B) The effect of $1000 \mathrm{mg} / \mathrm{L}$ dacarbazine on melanoma cells apoptosis. $* / * * * * *$ - significant differences in the percent of alive $\left(^{*}\right)$, early apoptotic $\left(^{* *}\right)$ and late apoptotic/necrotic $\left({ }^{* *}\right)$ cells after dacarbazine treatment $(p<0.05)$. (C) Migration and invasion assay results after $100 \mathrm{mg} / \mathrm{L}$ dacarbazine treatment of melanoma cells. * - significant as compared with negative control $(p<0.05)$. (D) Microscopy of migrated cells on polycarbonate membrane.

The study was supported by a grant from the Russian Foundation for Basic Research and Krasnoyarsk Regional Science Foundation (project № 16-44-242056). 